Katarzyna Roszewska

https://www.orcid.org/0000-0002-1452-2497/

Cardinal Stefan Wyszyński University in Warsaw

\title{
RISK OF INCAPACITY FOR WORK IN THE POLISH CONSTITUTION
}

\begin{abstract}
In the Polish legal system, risk of incapacity for work is subject to protection under the Constitution itself. The definition of said risk and the scope of its regulation under the Constitution were determined chiefly by political as well as socio-economic context in which the Constitution was adopted. The present article briefly discusses the conditions that determined the shape of the constitutional right to social security as well as its content and significance for the legislative changes covering the risk of incapacity for work.
\end{abstract}

Słowa kluczowe: niezdolność do pracy, polska konstytucja, prawo do zabezpieczenia społecznego

Keywords: incapacity for work, Polish Constitution, right to social security

ASJC: 3308, JEL: K31

\section{Risk of incapacity for work in the Constitution}

Risk of incapacity for work has always accompanied people who make a living from work. It has also been recognised in modern social security systems from the very outset. The Polish legislation on social rights has a rich history, although they have been presented in various ways. The significance of the risk of incapacity for work certainly ensured it a permanent place in the Polish constitutions, and the current scope of its regulation does not seem endangered. The right to social security in the event of incapacity for work has been invariably located in the Constitution among the economic, social and cultural rights and freedoms.

The current Polish Constitution from 1997 provides in Art. 67 for the right to social security in the event of incapacity for work due to disability in addition to the risks of sickness, reaching retirement age, and unemployment. The list raises concerns as incomplete (Wagner 2009, p. 346), ${ }^{1}$ since it does not cover the risks protected under

1 This is not characteristic for the Polish constitution only. Other states lack a coherent list of social rights, as well (Eichenhofer 2016, p. 141). Still, it ought to be remembered that in Germany, the fundamental social rights are regulated by the Social Code. 
the ILO Convention No. 102, which provides for minimum social security standards (Kolasiński 1999, p. 18; Zieleniecki 2005, pp. 580, 582). Numerous social issues subject to protection under international law concerning persons who are unfit for work are, however, regulated by other provisions of the Constitution. The Constitution provides for the protection of health (Art. 68) and aid to persons with disability to ensure their subsistence (Art. 69). Particular protection of the disabled may be based also on the constitutional provisions granting protection to the family and children (Art. 71 and 72 , respectively). The rights mentioned above are listed in one chapter concerning the freedoms, rights and obligations of persons and citizens and are located among the economic, social and cultural rights and freedoms. Apart from them, the Constitution provides for care of veterans of the struggle for independence, including war invalids (Art. 19, located in the chapter devoted to the Republic). Furthermore, the Constitution stipulates the condition for a judge to be retired on account of illness or infirmity which prevent them from discharging the duties of their office (Art. 180(3), chapter on courts and tribunals). In addition, the list of political rights and freedoms includes a reference to persons subjected to legal incapacitation in the context of the active electoral rights (Art. 62(2)).

Concepts such as incapacity for work on account of invalidity, illness, health or disability involve the protection of the related situations in a person's life. In addition, the borderline between them is not very distinct and their scopes sometimes overlap (the mutual relations of the risks listed among others in Art. 67, 68 and 69 were described by: Ślebzak 2015, pp. 82-91, 93-97). A particularly unfortunate solution is connecting incapacity for work on account of invalidity and incapacity for work due to illness. ${ }^{2}$ Essentially, these are after all two separate risks, which are differentiated based on long history and international standards. Moreover, it seems that the concept of invalidity in the Constitution was not correlated with the reform of the disability pension scheme, in the course of which the state gave up on the concept of invalidity in favour of the concept of incapacity for work only.

The current regulation of the risk of incapacity for work in the Constitution of 1997 does not form a natural continuation of the social solutions that were in force during the socialist period. The Constitution was adopted by the National Assembly in the situation of a far-reaching political compromise. Importantly, it was not the general regulation of those rights (which had its tradition in the Polish constitutionalism) but rather their final shape that was a subject of dispute. The opponents of a detailed regulation of the right to social security in the constitution believed that the

2 This sometimes leads to the idea that it represents one risk differentiated by cause (Ślebzak 2015 , p. 9; 2016, p. 1512). The same author takes into consideration a broader, international context and lists in total four risks of incapacity for work: illness as short-term incapacity for work, long-term or permanent incapacity for work, incapacity for work caused by an accident at work and by illness (Sanetra 2004, pp. 49-50), in turn, maintains that incapacity for work was treated as a collective premise of the right to social security in the event of, among others, illness, more serious cases of health disorder and reaching retirement age. 
state should not make empty promises and emphasised the need to verify whether they could be fulfilled (Kulesza 1995, p. 101; the works of this particular subcommittee were also deemed the most controversial). A contradictory view was based on the concept of rendering the state more sensitive to the situation of economically weaker social groups, particularly the sick, the elderly and the poor (Skrzydło 1999, p. 62; Bińczycka-Majewska 2004, p. 39).

The shape of social risks in the Constitution was influenced also by the ongoing political transformation and the uncertainty of the socio-economic situation. The devaluation of the legal regulations of social rights in the past era was still fresh in the mind. The direction of the reforms of the social security system, in particular the so called Second Pillar (pension funds), was still unclear. The ideas to introduce additional, voluntary insurance against social risks protected by public insurance funds met with various reactions (Balcerowicz 1995, p. 122; sceptic opinions: Świątkowski 1995/1996, p. 25, described as anachronic by: Zieliński 2004, p. 22). On the other hand, the example of other democratic constitutions and the influence of international law supported the concept to enshrine these rights in the constitution (Zakrzewska 1993, p. 53). Also creating in the Constitution the category of human and civil rights (and not only civil rights, as in the Constitution of the People's Republic of Poland) reflected international trends (Zakrzewski 2010, p. 168), although specifically the right to social security was awarded to citizens only (specific guarantees for the citizens of other states may be inferred from international and EU law). At the same time, the adopted solution is perceived as considerably more modest in comparison to the previous approach to the protection of social rights (although, as it was mentioned, those devalued in the period of planned economy), due to the fact that the Constitution of 1952 listed the institutional guarantees of these rights and obliged the state to develop the social insurance system (Garlicki, Jarosz-Żukowska 2016, p. 693). At present, this dynamism is understood rather as the response of social security systems to demographic challenges or socioeconomic changes, which might mean also weakening the protection, if the need arises. ${ }^{3}$ Another major normative change to the content of the risk in question as described in the Constitution entailed abandoning the insurance method in favour of the social security method. The legislature is no longer bound by a method of protection which involves participation in a common fund.

\footnotetext{
${ }^{3}$ It ought to be noted that the Committee of Social Rights requires the states parties to the European Social Charter (see Conclusions XIII-4, Statement of Interpretation, Art. 12(3)) to present information on changes in social security systems with regard to: the character of the changes (the scope of application, the terms of granting benefits, their amount and duration, etc.); the reasons for changes (the pursued objectives) and the context of the social and economic policy in which they appear; the extent of changes (the categories and number of involved persons, the scope of rights before and after the change); the means of social assistance for persons in need as a result of the changes (such information may be submitted under Art. 13); the results of such changes (their adequacy).
} 


\section{Changes in the perception of social risks}

The protection of social risks was fostered by the development of the welfare state, but also of an industrial society, where some of the risks (including the risk of incapacity for work) were even highlighted. Unemployment or accidents at work were even treated as unavoidable risks caused by industrial production processes (Van der Veen 2012, pp. 17-19 and the cited subject literature). The development of the welfare state was made possible by stabilising employment. Yet over time, the social and economic context of welfare states has changed fundamentally. There have been economic changes towards an open economy and socio-cultural changes towards an open society. The former involved globalisation, and the latter-individualisation. Processes taking place in distant parts of the world and ties within global networks began to have an increasing impact on our lives. At the same time, social relations began to relax and became less forced. This weakens state institutions and undermines their right to impose fiscal duties on the citizens (Van der Veen 2012, pp. 17-19 and the cited subject literature). For some time now, the burden of distributing benefits has been shifting towards investments in human capital, in individuals who have the capacity of and are ready for activity and social integration (Van der Veen 2012, p. 24). The emphasis is on flexibility and efficiency in solving social problems, which requires the involvement of benefit receivers. The changes made in social and family policies were supposed to make the passive public care system evolve towards one that would render the target groups more involved and active (Grewiński 2017, p. 200). Such changes are expected and designed also in legislation which shapes the protection of the risk of incapacity for work. In Poland, such hopes are connected to the idea of abolishing the disability pension trap. There is even draft legislation aiming to abolish disability pensioners' income limits which result in a reduction or suspension of the benefits (MP's bill...). At the same time, solutions have been sought for years now to activate people with impaired ability, which would allow them to avoid becoming disability pensioners and remain in the labour market. One of such solutions was the training disability pension, i.e. disability pension for the period of reskilling. Another plan has been made recently to develop a model of comprehensive rehabilitation that would help persons who cannot undertake or continue to perform social roles and professional activity on account of an injury, a disease, a congenital disability or a disability acquired in the course of their development undertake or resume social or professional activity. The comprehensive character of the rehabilitation should manifest itself in the simultaneous action taking into account four areas: therapeutic, psychological, professional and social. ${ }^{4}$

${ }^{4}$ A system project implemented by the State Fund for Rehabilitation of Disabled People (PFRON) in partnership with the Social Insurance Institution and the Central Institute for Labour ProtectionNational Research Institute, titled Development and pilot implementation of a model of comprehensive rehabilitation enabling taking up or returning to work, a conceptual system project carried out under the Operational Programme Knowledge Education Development from the funds of the European Union and 
The focus is therefore consistently shifted towards activating persons who have been excluded for various reasons (including disability, old age, unemployment or parenthood), which requires innovative actions on the part of the state and local authorities as well as new legislative solutions that would take into account the need for a comprehensive impact on the individual. As a result, the perception of traditional social risks is changing. It is even noted that success in dealing with problems faced by traditional welfare states may itself generate new risks for people who e.g. do less well in flexible labour markets (Taylor-Gooby 2004, pp. 236-237).

In this context, the question arises about the significance of the constitutional protection of social risks, which-given the permanence and stability of constitutional norms - may protect them against overly hasty, ad hoc changes, but on the other hand can hamper changes justified by socio-economic and demographic developments.

\section{The content of the constitutional right to social security in the event of incapacity for work}

The wording of Art. 67 of the Constitution leaves no doubt that the constitutional delegation largely transfers the obligation to determine the scope and form of social security to statutes (judgment of the Constitutional Tribunal of 20 November 2001, SK $15 / 01$, OTK-ZU 2001, No. 138, item 1564), which is perceived here as a weakening of the constitutional guarantees of protection (Morawska 2006, p. 244). On the one hand, there is no dispute with regard to the view that the right to social security is subjective and thus can be the source of legal protection and a basis for individual claims. On the other hand, the Constitutional Tribunal took the view that it is not possible to infer a constitutional right to a specific form of benefit under Art. 67 (judgment of the Constitutional Tribunal of 7 September 2004, SK 30/03, OTK-A 2004, No. 8 item. 82; judgment of the Constitutional Tribunal of 6 February 2002, SK 11/01, OTK-A 2002, No. 1, item 2). The guarantees under Art. 67(1) are understood as the requirement to ensure the essence of the right to social security, which in turn is construed as the normative content which determines the fundamental conditions for the operation of the right in question (minimum right) that should be guaranteed by the state. The rights which go beyond the constitutional essence of the discussed right may even be abolished, with due regard only for the constitutional principles and norms that determine the limits of the legislature's freedom to change the legal system (judgment of the Constitutional Tribunal of 7 February 2006, K 45/04, OTK-A 2006, No. 2, item 15).

The minimum content of the right to social security, which constitutes its essence, is understood as the obligation to ensure a minimum level of benefit, which has been criticised (Roszewska 2018, pp. 183-184). Construing the essence of the right to social

state budget. Information about the project: http://rehabilitacjakompleksowa.pfron.org.pl/informacjeo-projekcie/ (access: 20 January 2020). 
security as ensuring the subsistence minimum or living minimum is namely contrary to the function of the right to social security, which serves among others to substitute earned income. It is the function of social assistance to ensure a specific minimum (Ślebzak 2015, p. 139). The right to social security may not be treated as a specific minimum because it is not uniform in nature. It is not tantamount to all risks listed in national and international regulations. Even the Constitution itself draws a line between the rights inferred from Art. 67(1) and those inferred from Art. 67(2) (in the latter case, the right to social security is exercised taking into account the condition of lack of other means of subsistence; the diversity of the standard of protection is also due to international regulations, which we regard as the so-called minimum standard of protection). This right takes a different shape in the event of incapacity for work on account of invalidity, illness, reaching the pension age, etc. The scope of rights resulting from the right to social security can vary even with regard to one particular risk. Such differences within the risk of incapacity for work are based among others on the grounds for incapacity for work (e.g. general state of health vs accident at work) or the moment when the incapacity occurs (e.g. during childhood or education or during or after working life).

Finally, despite the general wording of Art. 67 of the Constitution, listing specific risks means that they should entail specific forms of protection that will ensure its optimal level. Even if it is not possible to infer a constitutional right to a specific form of social benefit (judgment of the Constitutional Tribunal of 6 February 2002, SK 11/01, OTK-A 2002, No. 1, item 2; judgments of the Supreme Court of 10 November 2010, III UK 5/10, OSNP 2012, No. 3-4, item 43; judgments of the Supreme Court of 24 June 2015, I UK 371/14, LEX 1771087) or a claim for a specific benefit on the basis of this provision (e.g. judgment of the Constitutional Tribunal of 7 September 2004, SK 30/03, OTK-A 2004, No. 8 item. 82; Judgment of the Supreme Court of 14 March 2002, III RN 141/01, OSNP 2002, No. 24, item 584; judgment of the Supreme Court of 13 April 2007, I CSK 488/06, OSNC 2008, No. 5, item 49), it is the legislature's responsibility to create an appropriate mechanism for society to support those in need of assistance in meeting their basic needs (judgment of the Constitutional Tribunal of 4 November 2014, K 1/14, OTK-A 2015, No. 10, item 163). In view of the vagueness of Art. 67(1), it is proposed to refer to the significance of the benefits for particular risks in the legislation. Disability pension is a long-term, non-returnable benefit which serves to protect against the consequences of random events that affect the social and living conditions of the individual. It is associated with the effects of a specific random event that affects the ability to work and to take up work and the benefits (Babińska-Górecka 2014, p. 225). The Constitutional Tribunal does not remain indifferent in its assessment of this form of protection and maintains that disability pension (in addition to old age pension) is a benefit that fulfils the guarantees under Art. 67(1) of the Constitution (judgment of the Constitutional Tribunal of 17 June 2014, P 6/12, OTK-A 2014, No. 6, item 62). ${ }^{5}$ In

${ }^{5}$ The right to social security within the meaning of Art. 67(1) of the Constitution is understood to involve also the right to social pension (Kolasiński 1999, p. 18; judgment of the Constitutional Tribunal 
other words, the right to social security in the event of incapacity for work should be exercised in such a way as to safeguard the risk of long-term income effects caused by physical impairment. Thus, by specifying certain risks, Art. 67(1) also determines specific forms of their protection.

The right to social security should be interpreted also with reference to the general principles of social freedoms and rights (Wujczyk 2015, p. 277; Roszewska 2018, pp. 194207). It is therefore not excluded that the proposed solutions may be subject to constitutional verification, including from the perspective of other constitutional provisions.

\section{Conclusions}

To sum up, social rights have a firm place in the Constitution, but should be subject to a dynamic interpretation. It is emphasised that the Constitution comprises not only provisions which support maintaining a system of social security, but also such that can restrict it (e.g. the principle of equilibrium; Wujczyk 2016, p. 285). According to the Constitutional Tribunal, the extent to which the right to social security will be implemented in normal statutes depends on the state's economic situation, the proportion of the number of persons who work to the number of tax payers, the number of beneficiaries and their wealth, the adopted social model of income protection in old age or in the period of decline in vitality, as well as the anticipated economic and social trends, in particular demographic trends (judgment of the Constitutional Tribunal of 7 May 2014, K 43/12, OTK-A 2014, No. 5, item 50).

At the same time, social rights as human rights should not depend entirely or essentially on statutes (Wujczyk 2016, p. 286). Art. 67 of the Constitution leaves considerable discretionary margin for reforming the system of protection against the risk of incapacity for work. However, the provision itself is not entirely devoid of content and reduced to a uniform minimum benefit. The wording of Art. 67 of the Constitution enables a broad approach to the protection of the risk of incapacity for work. It entails the protection of all citizens (other actors are subject to social security protection under international agreements or EU provisions on the coordination of social security schemes), not only those covered by social security or specific supply systems (e.g. for uniformed services). This means that the state is obliged to provide protection also to other people who are unable to work (in our system, these functions are performed, among others, by a fixed allowance and social insurance benefits granted under special regulations to persons who, as a result of special circumstances, do not meet the conditions to receive the benefit). The constitutional shape of risk protection does not

of 25 June 2013, P 11/12, OTK-A 2013/5, item 62) or the right to survivors' benefits as resulting from the right of the deceased (Jędrasik-Jankowska 2010, p. 282; judgment of the Constitutional Tribunal of 13 May 2014, SK 61/13, OTK-A 2014, No. 5, item 52 and earlier case law of the Constitutional Tribunal cited therein). 
interfere with its contemporary paradigm, either. It has gone from the risk of a working person to the risk of a person at working age. After all, the Constitution stipulates that the right to social security is not granted in case of "loss of capacity for work," but in case of "incapacity for work" (this is confirmed by the development of legal regulations in this area, in particular concerning the social pension).

In turn, the departure from the insurance method in favour of the right to social security renders the protection of risks more flexible. The state is obliged to seek and construct an entire set of norms for the protection of the risks specified in Art. 67 of the Constitution, which would optimally implement the principles and objectives of this right (Ślebzak 2016, p. 1516, on the obligation to protect social rights in the form of such a shape of statutory solutions which will optimally implement the content of constitutional law and the cited case law). Traditional benefits from the social security disability pension fund that are available to an individual do not ensure comprehensive protection of needs in case of incapacity for work. According to the modern understanding, the protection of the risk of incapacity for work should include both protection against lost or reduced income and protection of the possibility of regaining capacity for work and protection of the existing capacity for work.

\section{Bibliography}

Babińska-Górecka R. (2014) Skutki orzeczeń Trybunału Konstytucyjnego w dziedzinie ubezpieczenia społecznego, Warszawa.

Balcerowicz L. (1995) Wolność i rozwój. Ekonomia wolnego rynku, Kraków.

Bińczycka-Majewska T. (2004), Konstrukcja zabezpieczenia ryzyka starości w nowym systemie prawnym [in:] T. Bińczycka-Majewska (red.), Konstrukcje prawa emerytalnego, Kraków.

Eichenhofer E. The Right to Social Security in the European Constitutions, "Studia z Zakresu Prawa Pracy i Polityki Społecznej," nr 23.

Garlicki L., Jarosz-Żukowska S. (2016) [in:] L. Garlicki, M. Zubik (red.), Konstytucja Rzeczypospolitej Polskiej. Komentarz, t. 2, Warszawa.

Grewiński M. (2017) Blisko trzy dekady polskiego systemu pomocy społecznej w kontekście realizacji polityki społecznej [in:] P. Grata (red.), Od kwestii robotniczej do nowoczesnej kwestii socjalnej. Studia z polskiej polityki społecznej XX i XXI wieku, t. 5, Rzeszów.

Jędrasik-Jankowska I. (2010) Pojęcie i konstrukcje prawne ubezpieczenia społecznego, Warszawa.

Kolasiński K. (1999) Konstytucyjne prawo do zabezpieczenia społecznego a nowy system ubezpieczeń społecznych, "Państwo i Prawo," nr 5.

Kulesza W. (1995) [in:] “Biuletyn Komisji Konstytucyjnej Zgromadzenia Narodowego,” nr 10, Warszawa.

Morawska E. (2006) Prawa i wolności socjalne w Konstytucji RP. Zagadnienia systemowe, “Kwartalnik Prawa Publicznego," z. 2.

Roszewska K. (2018) Ryzyko niezdolności do pracy, Warszawa. 
Sanetra A. (2004) Spory na tle prawa do renty z tytułu niezdolności do pracy [in:] U. Jackowiak, A. Malaka (red.), Problemy ubezpieczeń społecznych w 70-lecie istnienia Zakładu Ubezpieczeń Społecznych, Wrocław.

Skrzydło W. (1999) Konstytucja Rzeczypospolitej Polskiej. Komentarz, Kraków.

Ślebzak K. (2015) Prawo do zabezpieczenia społecznego w Konstytucji RP. Zagadnienia podstawowe, Warszawa.

Ślebzak K. (2016) [in:] Konstytucja RP, t. 1: Komentarz do art. 1-86, ed. by M. Safjan, L. Bosek, Warszawa.

Świątkowski A. (1995/1996) Voluntary Benefit Plans: Economic Necessity or Political Fashion, "East-West Review of Social Policy," Vol. 1-2.

Taylor-Gooby P. (2004) New Social Risks and Welfare States: New Paradigm and New Politics? [in:] P. Taylor-Gooby (ed.), New Risks, New Welfare. The Transformation of the European Welfare State, Oxford.

Van der Veen R. (2010) Risk and the Welfare State [in:] R. Van der Veen, M. Yerkes, O. Achterberg (eds.), Risk and the Welfare State Risk, Risk Perception and Solidarity, Amsterdam.

Wagner B. (2009) Prawo do zabezpieczenia społecznego w Konstytucji RP [in:] A. Patulski, K. Walczak (red.), Jedność w różnorodności. Studia z zakresu prawa pracy, zabezpieczenia społecznego i polityki społecznej. Ksiega pamiątkowa dedykowana prof. W. Muszalskiemu, Warszawa.

Wujczyk M. (2015) The Right to Social Security in the Constitution of the Republic of Poland, "Studia z Zakresu Prawa Pracy i Polityki Społecznej," nr 23.

Zakrzewska J. (1993) Spór o Konstytucje, Warszawa.

Zakrzewski W. (2010) [in:] W. Skrzydło (red.), Polskie prawo konstytucyjne, Lublin.

Zieleniecki M. (2005) Prawo do zabezpieczenia społecznego, “Gdańskie Studia Prawnicze,” z. 13.

Zieliński T. (2004) Nowe emerytury - samoubezpieczenie na starość [in:] T. Bińczycka-Majewska (red.), Konstrukcje prawa emerytalnego, Kraków.

\section{Legal acts}

The Constitution of the Republic of Poland of 2 April 1997, Dz.U. 1997, No. 78, item 483 as amended.

MP's bill to amend the Funded Pensions Act and certain other acts [Poselski projekt ustawy o zmianie ustawy o emeryturach i rentach z Funduszu Ubezpieczeń Społecznych oraz niektórych innych ustaw], Sejm paper of the $9^{\text {th }}$ term of office No. 131, http://www.sejm. gov.pl/Sejm9.nsf/PrzebiegProc.xsp?nr=131 (access: 20 January 2020).

\section{Court sentences}

Judgment of the Constitutional Tribunal of 20 November 2001, SK 15/01, OTK-ZU 2001, No. 138, item 1564.

Judgment of the Constitutional Tribunal of 6 February 2002, SK 11/01, OTK-A 2002, No. 1, item 2. Judgment of the Supreme Court of 14 March 2002, III RN 141/01, OSNP 2002, No. 24, item 584. 
Judgment of the Constitutional Tribunal of 7 September 2004, SK 30/03, OTK-A 2004, No. 8, item. 82.

Judgment of the Constitutional Tribunal of 7 February 2006, K 45/04, OTK-A 2006, No. 2, item 15. Judgment of the Supreme Court of 13 April 2007, I CSK 488/06, OSNC 2008, No. 5, item 49. Judgment of the Constitutional Tribunal of 25 June 2013, P 11/12, OTK-A 2013, No. 5, item 62. Judgments of the Supreme Court of 10 November 2010, III UK 5/10, OSNP 2012, No. 3-4, item 43.

Judgment of the Constitutional Tribunal of 7 May 2014, K 43/12, OTK-A 2014, No. 5, item 50. Judgment of the Constitutional Tribunal of 13 May 2014, SK 61/13, OTK-A 2014, No. 5, item 52. Judgment of the Constitutional Tribunal of 17 June 2014, P 6/12, OTK-A 2014, No. 6, item 62. Judgment of the Constitutional Tribunal of 4 November 2014, K 1/14, OTK-A 2015, No. 10, item 163.

Judgments of the Supreme Court of 24 June 2015, I UK 371/14, LEX 1771087. 